\title{
Utilization of information technology in implementation active learning in private vocational school, PTPN 4 private vocational school Dolok Ilir in dealing with industrial revolution 4.0 era
}

\author{
Tulus $^{1 *}$, T.J. Marpaung ${ }^{1}$, Sawaluddin ${ }^{1}$, M.R. Syahputra ${ }^{1}$, Muhammad Zarlis ${ }^{2}$, \\ ${ }^{1}$ Departement of Mathematics, Universitas Sumatera Utara, Medan, Indonesia \\ ${ }^{2}$ Departement of Information Technology, Universitas Sumatera Utara, Medan, Indonesia \\ *Email: tulus@usu.ac.id
}

\begin{abstract}
After the millennium era, the development of information technology (IT) was sufficient quickly, changes in business patterns have also increased sharply. This is called the disruption era. IT technology has also penetrated the world of Education, both in management too learning method. In the world of education now the learning method is not only using conventional methods such as from textbooks and explanations from teachers only, but also with effective learning methods and efficiently by utilizing information technology. An example is the media multimedia based learning. Community service is wrong one way that can be used to carry out information technology correctional. Community service that will be carried out in this study is entitled Utilization of Information Technology in the Implementation of Active Learning in Schools PTPN4 Dolok Ilir Private Middle School In the Face of the Industrial Revolution Era 4.0, with the aim of helping teachers in the process of learning mathematics more interesting interactive and fun, because in general middle school students The first has many uses of telecommunications equipment that is equipped with various kinds of multimedia. The result of this service learning media will be made mathematics that includes the problem of building and space in accordance with the curriculum Junior high school.
\end{abstract}

Keywords: Social Service, Industry, Learning, Technology

\begin{abstract}
Abstrak
Pasca era millennium, dengan perkembangan teknologi informasi (IT) yang cukup cepat, perubahan pola bisnis juga meningkat tajam. Ini yang dinamakan era disrupsi. Teknologi IT juga telah merambah dunia Pendidikan, baik dalam manajemen juga metode penmebalajaran. Dalam dunia pendidikan kini metode pembelajaran tidak hanya menggunakan metode konvensional seperti dari buku-buku pelajaran dan penjelasan dari guru saja, namun juga dengan metode pembelajaran yang efektif dan efisien dengan memenfaatkan teknologi informasi. Sebagai contoh adalah media pembelajaran yang berbasis multimedia. Pengabdian pada masyarakat merupakan salah satu cara yang dapat dipakai untuk melaksanakan pemasyarakatan teknologi informasi. Pengabdian kepada masyarakat yang akan dilakukan pada penelitian ini berjudul Pemanfaatan Teknologi Informasi Dalam Pelaksanaan Pembelajaran Aktif Di Sekolah SMP Swasta PTPN4 Dolok Ilir Dalam Menghadapi Era Revolusi Industri 4.0, dengan tujuan membantu guru-guru dalam proses pembelajaran matematika yang lebih menarik interaktif dan menyenangkan, karena secara umum siswa sekolah menengah pertama telah banyak menggunakan alat telekomunikasi yang dilengkapi dengan berbagai macam multimedia. Hasil yang dicapai pada pengabdian ini akan dibuat media pembelajaran matematika yang mencakup masalah bangun dan ruang yang sesuai dengan kurikulum sekolah menengah pertama.
\end{abstract}

Kata Kunci: Pelayanan Masyarakat, Industri, Pembelajaran, Teknologi

\section{PENDAhUluan}

Dalam dunia komputer dikenal istilah animasi. Animasi merupakan salah satu bagian grafika komputer yang menyajikan tampilan yang sangat atraktif. Pemanfaatan animasi dapat ditujukan untuk similasi, menarik perhatian pemakai computer pada bagian tertentu pada layar, menampilkan 
keluaran program dengan gambar-gambar yang menarik dibandingkan dengan sederetan angka atau huruf. Dengan adanya aplikasi ini diharapkan dapat memudahkan dam menyenangkan dalam memahami dan mempelajari materi yang diberikan. Penggantian sistem ini diharapkan dapat memberikan informasi yang akurat, menghemat biaya dan waktu, sehingga dalam proses belajar mengajar seluruh siswa dapat mengerti materi pelajaran tersebut. Begitu juga perancangan animasi ini dapat memberikan motivasi terhadap siswa dalam hal pembelajaran matematika khususya masalah bangun bidang dan ruang.

Dalam hal mencari solusi untuk mengatasi masalah tersebut, sehingga dapat meningkatkan minat belajar dan prestasi belajar siswa pada pelajaran matematika. Dalam kegiatan belajar mengajar ketidakjelasan dan banyaknya materi yang disampaikan dapat dibantu dengan menghadirkan media sebagai perantara. Kerumitan bahan pelajaran dapat disederhanakan dengan bantuan media, karena media dapat mewakili apa yang kurang mampu disampaikan melalui katakata atau kalimat. Oleh karena itu dalam rangka membantu meningkatkan mutu pendidikan dan pengajaran matematika khususnya, maka perlu memanfaatkan perkembangan teknologi komputer.

\section{METODE PELAKSANAAN}

Kegiatan ini akan dilaksanakan pada kurun waktu Bulan Mei sampai dengan Bulan Agustus dengan memberikan pelatihan bagi guru-guru SMP dengan tujuan, guru dapat melaksanakan kegiatan belajar mengajar menggunakan metode pembelajaran aktif. Pelaksana pengabdian akan memberikan pelatihan tentang penyiapan Rencana Proses Pembelajaran berbasis Pembelajaran Aktif. Selanjutnya juga diberikan pelatihan Pembuatan Bahan Ajar yang berbasis Metode Pembelajaran Aktif dengan menggunakan Teknologi Informasi, baik menggunakan Power Point maupun penyiapan bahan berbentuk video pembelajaran. Untuk keberlanjutan dari pelatihan yang diberikan, mitra akan diberikan perangkat komputer beserta infokus, sehingga metode pembelajar aktif di kelas dapat diteruskan. Pelaksanaan Pengabdian ini akan dilakukan dalam tiga tahapan besar, yaitu:

1. Pelaksanaan Forum Group Discussion (FGD)

FGD dilaksanakan untuk curah pendapat yang akan memberikan masukan kepada Pelaksana Pengabdian terkait masalah-masalah utama di SMP Swasta PTPN4 Dolok Ilir. Dalam FGD ini akan diundang para guru dan staf Perkebunan. Kegiatan ini akan dilaksanakan di bulan Mei 2019.

2. Pelatihan Penyiapan Rencana Proses Pembelajaran.

Pelatihan ini dilaksanakan dengan menghadirkan semua guru-guru di SMP dengan tujuan para guru dapat menyusun RPP berbasis pembelajaran aktif. Kegiatan ini akan dilakukan oleh Pelaksana Pengabdian sendiri. Kegiatan akan dilaksanakan pada Bulan Juni 2019 setelah lebaran.

3. Pelatihan Pembuatan Bahan Ajar berbasis Teknologi Informasi.

Pelatihan ini akan difokuskan kepada Guru Mata Pelajaran dengan bidang masingmasing. Peserta pelatihan dikelompokkan ke dalam beberapa kelompok, sehingga bisa fokus langsung menggunakan komputer. Kegiatan ini akan dilaksanakan dalam bulan Juli atau Agustus 2019.

Metode yang akan dilakukan pada pelaksanaan pengabdian ini adalah:

1. Mendapatkan data yang berupa informasi yang diambil dari buku atau kurikulum pelajaran matematika khusus materi yang akan dibuat aplikasi pembelajaran nya.

2. Melakukan identifikasi bagaimana membuat agar materi yang dikaji menjadi lebih mudah dipelajari oleh siswa SMP.

3. Untuk menarik minat belajar siswa pada materi ini, akan dibuat aplikasi pembelajaran yang materinya dikemas seefisien mumgkin, sehingga siswa dapat berinteraksi dengan aplikasi tersebut. 
4. Melakukan perancangan aplikasi pembelajaran, mulai dari membuat tampilan aplikasi, penyusunan materi, latihan dan soal.

5. Setelah perancangan rampung dan diperoleh hasil yang maksimal, maka dilakukan pembagian aplikasi ini ke sekolah dan membuat pelatihan /workshop kepada guru matematika atau siswa.

Dalam pelaksanaan pengabdian ini, akan dibantu oleh satu alumni dari Matematika USU dan lima mahasiswa dari Matematika USU yaitu:

1. Tulus Joseph Herianto (Alumni)

2. Jonathan Liviera Marpaung (Mahasiswa / NIM : 150803048)

3. Husein Aziz Aroyhan (Mahasiswa / NIM : 150803036)

4. Denny Setiawan (Mahasiswa / NIM : 150803007)

5. Arianto (Mahasiswa / NIM : 150803054)

6. Nurhasanah Widyasari (Mahasiswa / NIM : 150803002)

\section{HASIL DAN PEMBAHASAN}

\subsection{Focus Group Discussion (FGD)}

Kegiatan FGD bertujuan untuk melakukan diskusi awal dalam mempelajari dan mengetahui perkembangan sekolah didalam melaksanakan pembelajaran untuk siswa/i di SMP Swasta 1 PTPN IV Dolokilir. Kegiatan dihadiri oleh Kepala Sekolah SMP Swasta 1 PTPN IV, Guru, pegawai Tata Usaha, dan Orang tua murid. Kegiatan dibuka oleh ketua Tim Pengabdian Pada Masyarakat dan di bawakan oleh anggota Tim pengabdian pada masyarakat.

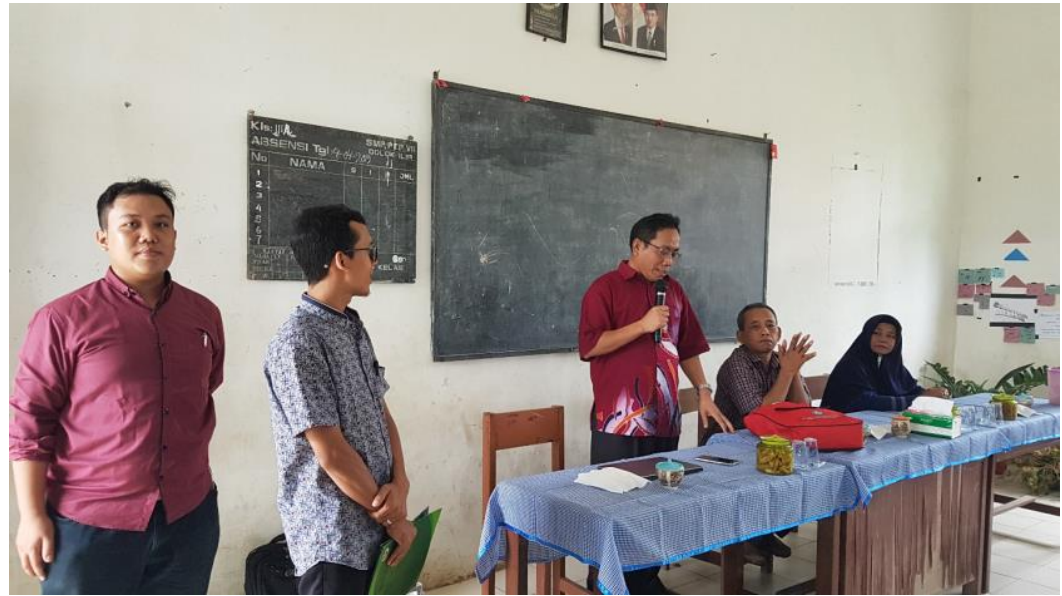

Gambar 3.1 Kata Pembukaan oleh Ketua Tim Pengabdian USU

Adapun kegiatan ini mengikutsertakan alumni SMP Swasta PTPN IV Dolok Ilir, Staf, Guru dan masyarakat. Dari hasil diskusi disepakati bahwasanya bantuan sarana dan prasarana sangat dibutuhkan oleh SMP Swasta PTPN IV Dolok Ilir. Dan juga bantuan akses jalan dan transportasi menuju sekolah ini. Alumni juga sebagai stackholder menyepakati bahwasanya dari FGD ini akan membantu perkembangan SMP Swasta PTPN IV Dolok Ilir semaksimal mungkin demi mewujudkan pendidikan di SMP Swasta PTPN IV Dolok Ilir semakin lebih baik dan menghasilkan alumni-alumni yang bisa dibanggakan suatu saat nanti. 


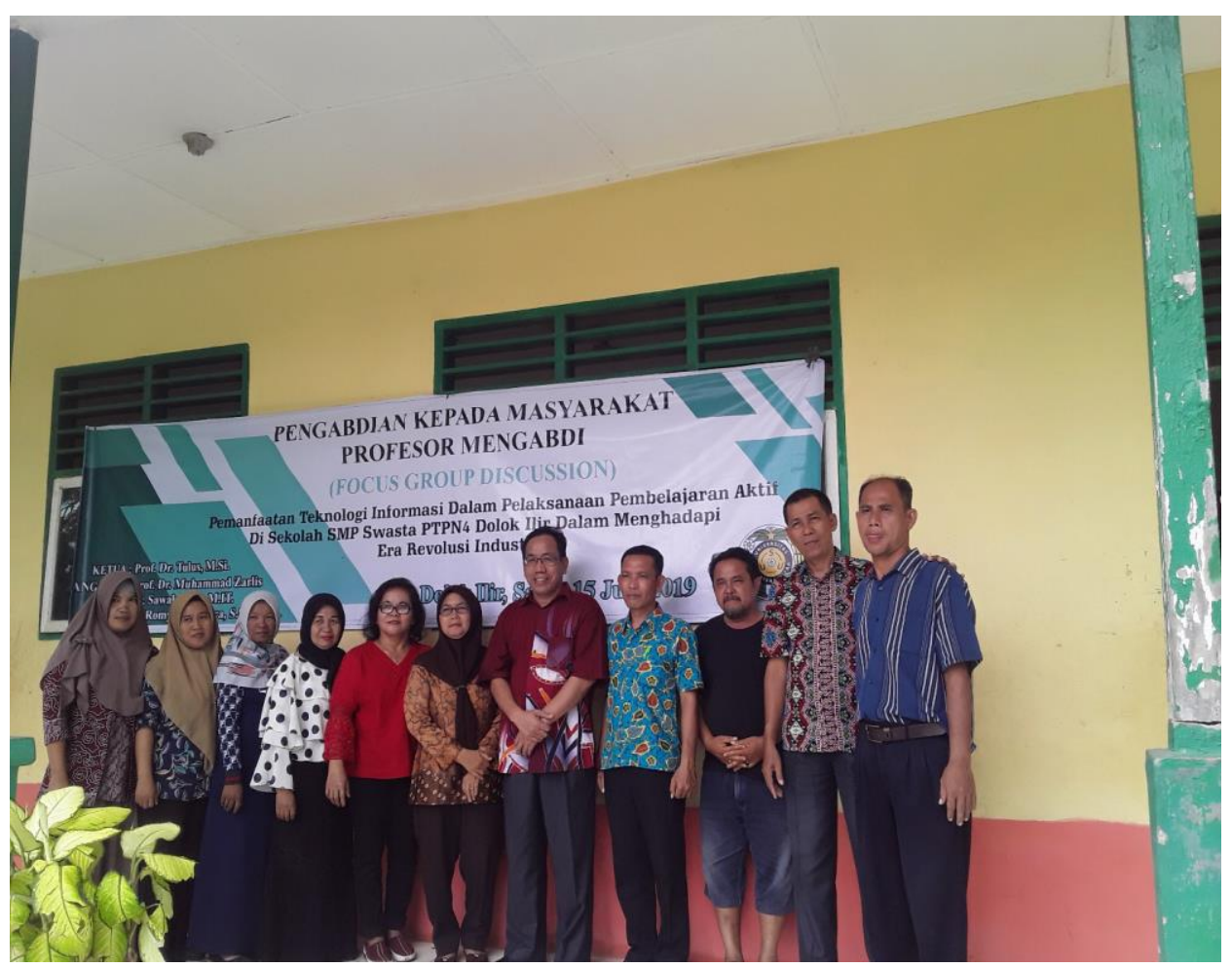

Gambar 3.2 Foto bersama Alumni, Staf dan Guru SMP Swasta PTPN IV Dolok Ilir

\subsection{Pelatihan Pembelajaran Aktif di Sekolah}

Pada tahap kedua telah dilakukan pelatihan di dalam pelatihan pembelajaran aktif di sekolah yang ditujukan kepada guru dan staf SMP Swasta 1 PTPN IV Dolok ilir. Pelatihan dipimpin langsung oleh ketua Tim dalam memberikan metode pembelajaran yang berbeda yang dapat di terapkan kepada siswa/i di sekolah. Pelatihan yang dilakukan diharapkan mampu memberikan edukasi kepada para guru supaya tidak melupakan nilai-nilai yang harus dilakukan disetiap kegiatan belajar mengajar yang akan dilakukan seperti mengucap salam, berdoa, menyanyikan lagu bernuansa Nasionalisme dan nilai-nilai Pancasila ditengah-tengah kehidupan bermasyarakat.

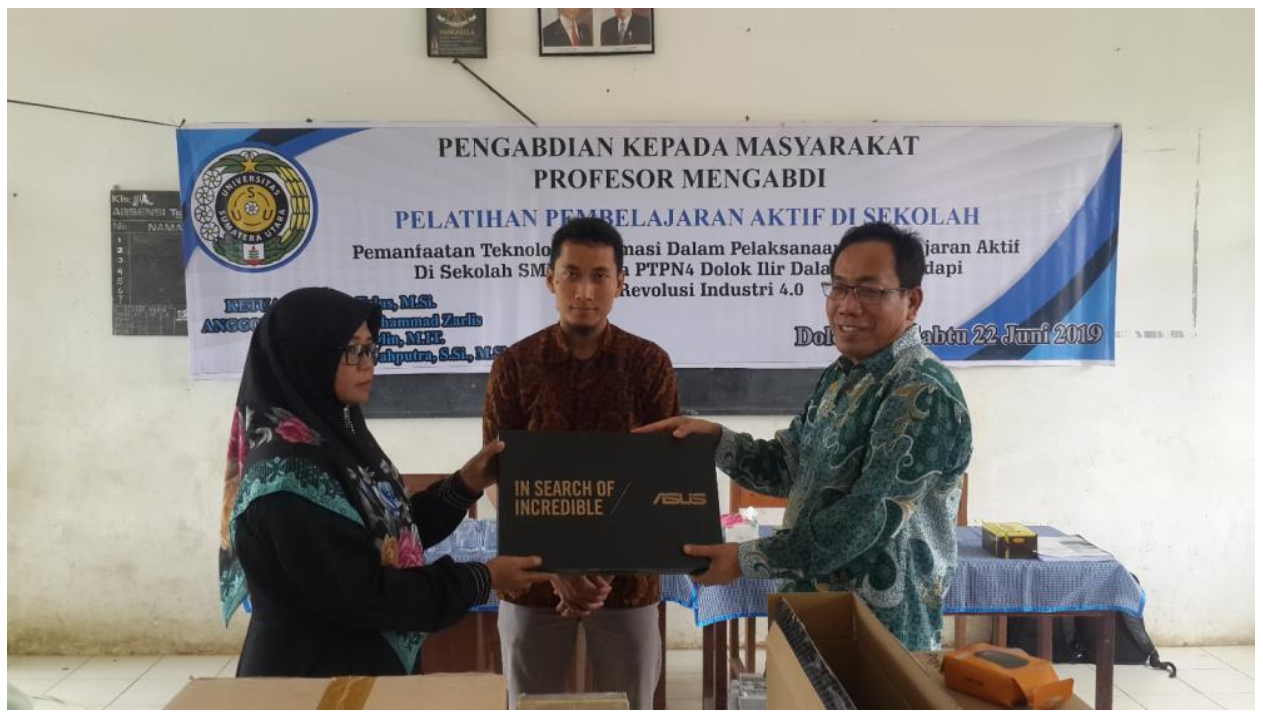

Gambar 3.3 Serah Terima Perangkat Pendukung Pembelajaran Aktif di Sekolah 
Kegiatan dihadiri oleh perwakilan pimpinan Yayasan sekolah PTPN IV dan selanjutnya dilakukan serah terima perangkat pendukung dalam menciptakan pembelajaran aktif di sekolah kepada Kepala Sekolah SMP Swasta 1 Dolokilir yaitu berupa 1 set Laptop, 1 set Torso rangka tubuh manusia, 1 unit proyektor, 1 unit layar proyektor, bola voli,dan bola kaki. Seluruh perangkat diberikan guna mendukung peran sekolah di dalam menciptakan suasana pembelajaran baru dengan mengedepankan keaktifan siswa/i di dalam lingkungan sekolah. Harapan dari pemberian bantuan sarana ini yaitu SMP PTPN IV Dolok Ilir dapat membantu staf dan guru untuk kegiatan di sekolah terutama kegiatan belajar mengajar. Dan juga siswa dapat menikmati fasilitas yang memang diperlukan oleh mereka dan menambah semangat belajara setiap siswa/i SMP PTPN IV Dolok Ilir.

\subsection{Pelatihan Pemanfaatan Teknologi Informasi dan Komunikasi di Sekolah}

Kegiatan selanjutnya yang akan dilakukan adalah pelatihan pemanfaatan TIK di lingkungan sekolah dalam pembuatan media pembelajaran aktif berbasis teknologi. Kegiatan akan dilaksanakan dengan menggunakan seluruh perangkat yang telah diberikan tim pengabdian USU supaya para Guru dan Staf dapat menggunakan seluruh alat sebagaimana mestinya. Kegiatan selanjutnya akan lebih berfokus pada penerapan beberapa metode pembelajaran modern di sekolah yaitu dengan memanfaatkan media pembelajaran berbasis visual video dan audio visual dan diharapkan para guru mampu menyajikan kegiatan belajar mengajar yang aktif dan menyenangkan dengan suasana yang baru. Pemanfaatan Teknologi Informasi dan Komunikasi sangat penting mengingat Indonesia sudah memasuki era 4.0 sehingga seluruh Sumber Daya Manusia harus memahami tentang Teknologi dan bagaimana pemanfaatannya dalam kehidupan sehari-hari.

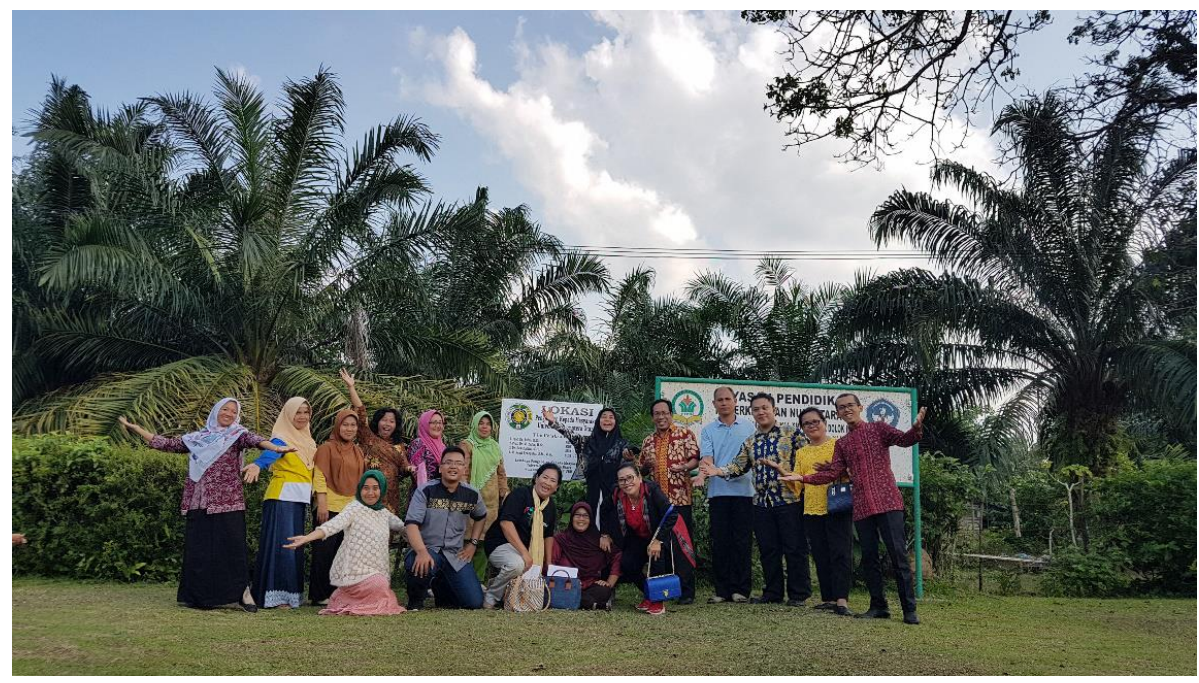

Gambar 3.4 Foto bersama mengakhiri kegiatan pengabdian masyarakat di depan plang

\section{KESIMPULAN}

Pemanfaatan teknologi informasi dalam media pembelajaran dapat memberikan dampak positif dalam kegiatan belajar mengajar di sekolah yaitu Menarik minat belajar siswa dan meningkatkan pemahaman siswa Sekolah Menengah Pertama, Dapat digunakan sebagai alat bantu bagi guru dalam menyampaikan materi secara menarik, efektif dan efisien, baik waktu dan tenaga.Media pembelajaran juga dapat digunakan bersama-sama, baik dikelas atau di pelajari secara mandiri. Disamping itu pemanfaatan teknologi yang baik di sekolah dapat meningkatkan mutu Pendidikan dalam segi efektifitas pembelajaran sehingga dapat meningkatkan mutu pendidikan di tingkat Sekolah Menengah Pertama. 


\section{UCAPAN TERIMAKASIH}

Penulis mengucapkan terima kasih kepada LPPM USU melalui dana Non PNBP Universitas Sumatera Utara sesuai dengan Surat Perjanjian Penugasan Pelaksanaan Pengabdian Kepada Masyarakat Program IBKIK Tahun Anggaran 2017 Nomor : 3223/UN5.2.3.2.1/PPM/2017, Tanggal 24 Juli 2017.

\section{DAFTAR PUSTAKA}

Beattie, S., 2005, Active Teaching Strategis, Baker College.

Kaufman, D. Sutow, E. \& Dunn, K., Three Approaches to Cooperative Learning in Higher Education, The Canadian Journal of Higher Education, Vol. XXVII, No. 2,3 p. 37-66

Ledlow, S., 1999, Cooperative Learning in Higher Educational, Centre for learning and Teaching Excellence, Arizona State University

Keyser, M. W., Active learning and cooperative learning: understanding the difference and using both styles effectively, Research Strategics, Vol. 17, p. 35-44

Ragains, P. 1995., Four variations in Drueke's active learning paradigm. Research strategies 13 (Winter), 40-50

Stahl F, Ashworth SH, Jandt KD, Mills RW. Light-emitting diode (LED) polymerization of dental composites: flexural properties and polymerization potential. J Biomater 2000; 21 : 1379-85

Suherman, E. dkk. 2003. Strategi Pembelajaran Aktif Kontemporer. Bandung. Universitas Pendidikan Indonesia 